\title{
Acceleration Strategy of Bali's Tourism Sector Amid COVID-19 Pandemic
}

\author{
I Wayan Suwendra, ${ }^{1, *}$ I Nyoman Sujana ${ }^{2}$ M. Rudi Irwansyah ${ }^{3}$ \\ 1,2,3 Department of Economic Education, Universitas Pendidikan Ganesha, Singaraja, Indonesia \\ *Corresponding author. Email: wayan.suwendra@undiksha.ac.id
}

\begin{abstract}
The aim of this research is to find out the impact of COVID-19 pandemic related to the tourism sector in Bali and the acceleration strategy of Bali's tourism sector amid COVID-19 pandemic. The research method used a qualitative approach which is descriptive by nature. The data collection used literature review and interview. The impacts brought by COVID-19 pandemic consist of economic impact, PHR revenue, employment, and brand image, triggered by the downward of tourists' visit or tourism sector ran into very deep contraction. There is a need for strategic plan to recover the level of tourists' visit to Bali. Acceleration strategy of tourism sector amid COVID-19 pandemic is through the strategy of Policy/regulation, community involvement, cooperation and promotion
\end{abstract}

Keywords: Community involvement, Cooperation, Promotion, Regulation

\section{INTRODUCTION}

COVID-19, which was originally emerged in China in the late of 2019, is spreading globally covering wide geographic area and becoming a pandemic. In a short time, the whole world eventually felt the ferocity of that virus. Various efforts have been done by countries to limit the spread of the virus with various terms such as lockdown, Large Scale Social Restriction (PSPB), social distancing, and so forth.

Data from task unit of National COVID-19 Management (https://covid19.go.id), shows the trend that each day undergoes reduction but still in the range of more than 300 thousand. Various efforts have been made by Indonesian government, both with preventive and curative methods. COVID-19 is not only causing health effects but also gives rise to its socioeconomic after effect. Restrictions carried out by the government both nationally and regionally with various methods raises quite significant implication, various research findings suggesting COVID-19 affects economically, among others [1] suggested that the impact of COVID19 towards UMKM in Indonesia, from about 37,000 UMKM existing, 56 percent reporting sales decrease, 22 percent reporting problem on financing aspect, 15 percent on distribution of goods and 4 percent having difficulty to get raw materials. In line with research findings, it is also revealed by [2] 5 aspects affected by COVID-19 for the tourism sector in Bandung, namely
Economy, Tax, Employment, Brand Image and continuity of tourism business.

Bali, for 46 years, had been assigned as a leading sector by the government to utilize optimally the tourism potential owned by Bali Province in the form of cultural uniqueness and natural beauty. Tourism sector is a major industry of Bali's economy, it is reflected from the amount of business share related to PDRB. Share of business providing accommodation and food \& beverages, is registered as major businesses and showing increasing share in the last 10 years, followed by the agricultural sector as a second business field. Furthermore, the number of tourists visiting Bali also continued to increase, although more and more new tourist destinations emerged in Indonesia.

In 2019, the composition of tourists visiting Bali were dominated by domestic tourists, with share of $62.7 \%$. Next was international tourists at $37 \%$. International tourists, based on the origin country, still dominated by Australia (19.9\%), followed by China $(18.9 \%)$, and India $(5.9 \%)$. In general, tourists visiting Bali were still centered in the Regency of Badung, Gianyar, and Tabanan. High concentration of tourists going into those three regions indirectly pushed the acceleration of economic activities that eventually pushed the increase of income per capita in those regions. 
The condition of tourists' visits to Bali in 2020 is in contrast to the condition in 2019. Based on Data from BPS-Bali (August 2020), shows that the visit of international tourists to Bali in the downward trend which can be described that in January 2020, 552,403 tourists came, next 327 tourists came in April 2020 and 22 visitations in August 2020. This condition was due to COVID-19 pandemic.

Actually, the test and challenge to the tourism of Bali not only happening now but also happened in the past, among others in the tragedy of humanity of Bali's bombing in 2002 and in 2005. The effort for recovery at that time [3]. It was stated that the strategy for tourism recovery was done by way of security restoration and tourism promotion. Later in 2017, Bali also went through the test to its tourism when Mount Agung erupted, which also contributed to the decrease of tourists visiting Bali. The presence of tourism recovery steps quoted from http://kompas. com. Arif Yahya, Tourism Minister at that time said that there were four steps to recover Bali tourism post Mount Agung eruption, among others, revoked travel warning, promotion of Bali tourism, come to Bali movement and disaster mitigation. The strategies that must be done not only at the less fortunate moment but also strategy when facing an opportunity such as the finding result of the study by Victoria lelu Sabon, 2018. It was said that factors influencing the performance of Indonesian tourism sector in welcoming the AEC were, namely the strategy of marketing, the strategy of funding, strategy of infra-structure development, policy in tourism sector and community involvement.

The cessation of the tourism sector is not only affecting tourism operators directly, but also to tourism supported industrial sector such as transportation service, hotel, and so forth. Tourism observer Chusmeru suggested that tourism sector was a service industry which was very sensitive to issues and security disruption. Similarly, the Head of Bali Tourism Agency Putu Astawa (http:// phinemo.com) stated that tourism industry was an economic sector which was very sensitive to the issue of human safety. Compared to the monetary crisis in 1998, Bali's bombing event, and the eruption of Mount Agung, the pandemic made zero visit to Bali.

In the tourism industry, there is an interesting topic towards handling strategy being done for tourism recovery, depending on what causing it. Based on research findings and expert' suggestions show that there is no similarity in strategy being done in tourism recovery. COVID-19 pandemic is a natural disaster experienced by almost every country in the world. The difference of its causative event makes the researchers interested to reveal what effect caused by this COVID-19 pandemic and what strategies to be implemented in order to accelerate Bali tourism sector amid COVID-19 pandemic.

\section{LITERATURE REVIEW}

\subsection{Strategy}

The word strategy is often heard in the military world and in business world. The word strategy originated from Greek language, which is a combination of the word stragos means soldier and egos means the leader. Strategy is an overall approach related to the implementation of idea, planning, and execution of an activity in a period of time. In good strategy there is coordination of the work team, has a theme, identifying supporting factors which are in line with the principles of implementation of ideas rationally, efficient in funding, and has tactics to achieve the goal effectively.

Business strategy involves decision making at business unit level. In strategy of this level the aim is how to compete. The useful approach in formulating business strategy is better based on competition analysis first suggested by Michael Porter. Reference [4] said strategy was how to position the organization to become something unique and valuable by making decisions regarding what to be done and what not to be done and later making adjustments from the whole organization's activities. In this context, then the strategy in question is in the field of tourism.

\subsection{Tourism}

Tourism is defined as a process of temporary departure of one person or more into another place outside of their residences. The drive of their departure is due to various interests in economy, social, cultural, politic, religion, health or other interests. It is suggested that tourism was one of a new type of industry which was able to accelerate economic growth and provide employment, improvement of income, standard of life as well as stimulating other productive sectors. Further, as a complex sector, tourism also made real use of classical industries such as handicraft and souvenir industries, lodging and transportation. From these two definitions it can be concluded that tourism is a process of departure by one person or more which from their departure into a destination has economic impact on that destination.

\subsection{COVID-19 Pandemic}

[5] Coronavirus is a group of viruses which cause disease in animals or humans. Several types of coronavirus which is known to cause infection of the respiratory tract in humans starting from coughing and cold up to more serious symptoms like Middle East Respiratory Syndrome (MERS) and Severe Acute Respiratory Syndrome (SARS). New type of coronavirus was found to cause COVID-19 disease. Further WHO also describes how COVID-19 virus is spreading. People can be infected with COVID-19 virus from another person who is being infected by this virus. 
COVID-19 can spread especially from person to person through a splash from the nose or mouth which comes out when a person infected with COVID-19 is coughing, sneezing or talking. These splashes are relatively heavy, the distance is not far and falling to the ground quickly. People can be infected with COVID-19 if inhaling the splash from the person infected with this virus. Therefore, it is important for us to keep distancing at least 1 meter from another person. The splashes can stick to objects and other surfaces around people such as table, door knob, and hand clasp. People can be infected by touching the object or surface, and later touching their eyes, nose or mouth. That's why it is important to wash hands regularly with soap and flowing clean water, or cleans it with antiseptic liquid made of alcohol. WHO is continuously examining research development regarding the way COVID-19 is spreading and will deliver new findings?

\subsection{Acceleration}

Acceleration describes the higher growth in the period of reporting compared to a certain period, in this the case acceleration depicts how the growth and development of Bali tourism with indicators of visit rate and occupancy rate of accommodation in Bali. Based on data of Bali tourism development by using international tourist visit as main indicators, it shows very deep contraction from quarter I to quarter II.

\subsection{Regulation}

Regulation is an abstract concept of complex system management in accordance with a set of rules and trends. [6] that regulation is a rule which being designed, formulated, constructed or made in such a way to help controlling a group of community, institution, organization, and companies with certain objective. In general, the main objective of the issuance of a regulation or rule is to control a group of people or community with certain restrictions. Regulation is enforced on various types of elements of society and community institution, whether it is for general purpose or for business purpose. But in general, the term of regulation is used to describe a form of applicable rule in social life. In the business field, there are various regulations issued by the government to control every business activity so as to create a good business ecosystem. Meanwhile the meaning of business regulation is the rules issued to control business behaviour, either regulation in the form of legal restriction by central or regional government, regulation of trade association, regulation of industry, and other regulations. So, it can be concluded that, the definition of business regulation is the ethics, rules or restrictions which must be fulfilled by business operators in running their business activities. Besides binding rules, the function of business regulation is to put in order the behaviour of entrepreneurs and consumers within certain limits. It is includeed in the regulations in tourism field.

\subsection{Factors influencing the Performance of Tourism sector}

There are several factors influencing the performance of tourism sector. As suggested by [7] that factors influencing the performance of Indonesian tourism sector in welcoming the AEC, namely the strategy of marketing, strategy of funding, strategy of infrastructure development, policy in tourism sector and public involvement. There are three marketing strategies being used, in order to improve tourists' visit in Indonesia namely, Destination, Origin and Timeline (DOT), the second strategy being used in marketing of Indonesian tourism is Branding, Advertising and Selling (BAS) and the third strategy being used in marketing is cooperation with media. Funding strategy, based on data of domestic investment and foreign investment, there is an increase of investment in Indonesia, therefore the funding prospect for the tourism sector can also be improved. Based on the Law of Republic of Indonesia Number 10 year 2009 regarding Tourism it is stated that tourism funding to become a shared responsibility, by central and regional government, entrepreneurs and public. Further the policy on tourism sector, there is a policy of visa exemption which is regulated in the Regulation of President of Republic of Indonesia Number 104 year 2015 regarding Visa free visitation. Regulation is needed to be able to manage and control the performance increase of tourism. It is also suggested that tourism policy needs to be implemented in order to accelerate economic growth and improvement of Indonesian tourism. Similar tone also being suggested by [8], that tourist destinations are able to give contribution for the increase of locally generated revenue. Next strategy is community involvement. The government is required to involve an active role from the public in developing the tourism sector which will have a significant effect on the economy of local community [9]. This is can be seen in the regency of Banyuwangi which able to develop tourism based on community

\subsection{Bubble Travel}

Reference [10] said that the travel bubble is a limited opening of one country to several other countries which have low and under control of corona virus cases (COVID-19). Currently, Indonesian government is planning the implementation of travel bubble with China, South Korea, Japan, and Australia. Deputy for Tourism Coordination and Creative Economy of the Coordinating Ministry of Maritime and Investment, Odo R.M. Manuhutu, said that the trend of bubble travel initially was intended for entrepreneur who would go abroad. Nevertheless, he was not dismissed that international tourists also would be interested to visit later. "After businessmen start to come, naturally it will also attract 
tourists to come", said Odo in virtual press conference, Friday (12/06/2020). Odo said, type of tourism which will be prioritized is natural tourism, looking at tourism trend in several countries, such as South Korea, Japan, and China. According to him, their people currently tend to select natural tourism which is not too crowded. One of the strengths of Indonesia, as Odo said, is still many natural tourist destinations which are still unexplored any further. "It can be an opportunity, exploring the strength of tourist destinations in the region. Labuan Bajo, area of Liang Ndara, maybe can be a location where they will be attracted for", said Odo. "This is a strategy to encourage people to promote their respective regions"

\subsection{Digital Nomad}

Digital Nomad is a person who is independent and flexible from the aspect of place and time, actually his/her life must be connected to three main resources: a set of Broadband Smart devices, and quick access to Internet, which enable long distance communication and eventually able to access data that they stored in digital storage (clouds/G-drive), (Makimoto, 2013). Digital Nomad is a person who is continuously moving and exploring new destinations but still dependent on technology to communicate so that they still can connect with their clients. The first person depicted as Digital Nomad was Steve K. Roberts, he made a lying bicycle which was computerized and traveling across the United States and named himself as high-tech Nomad (Robert in Purgat, 2018).

From theoretical exposure a research framework can be made which appears as seen in Picture.1.

\section{METHOD}

Research approach being used in this research is qualitative research approach. Qualitative research is a descriptive study. Based on the qualitative research approach then the researchers were using data sampling technique by way of literature study and interview. Interview technique was carried out by involving three components of informant or sources, namely government in this instance was tourism agency, tourism operators, and tourism observers. Analysis technique being used in this research was descriptive analysis, and with this approach will yield an analysis result in the form of description regarding tourism reality naturally in Bali related to the things as follows: First, how about the impact of COVID-19 pandemic towards tourism in Bali.

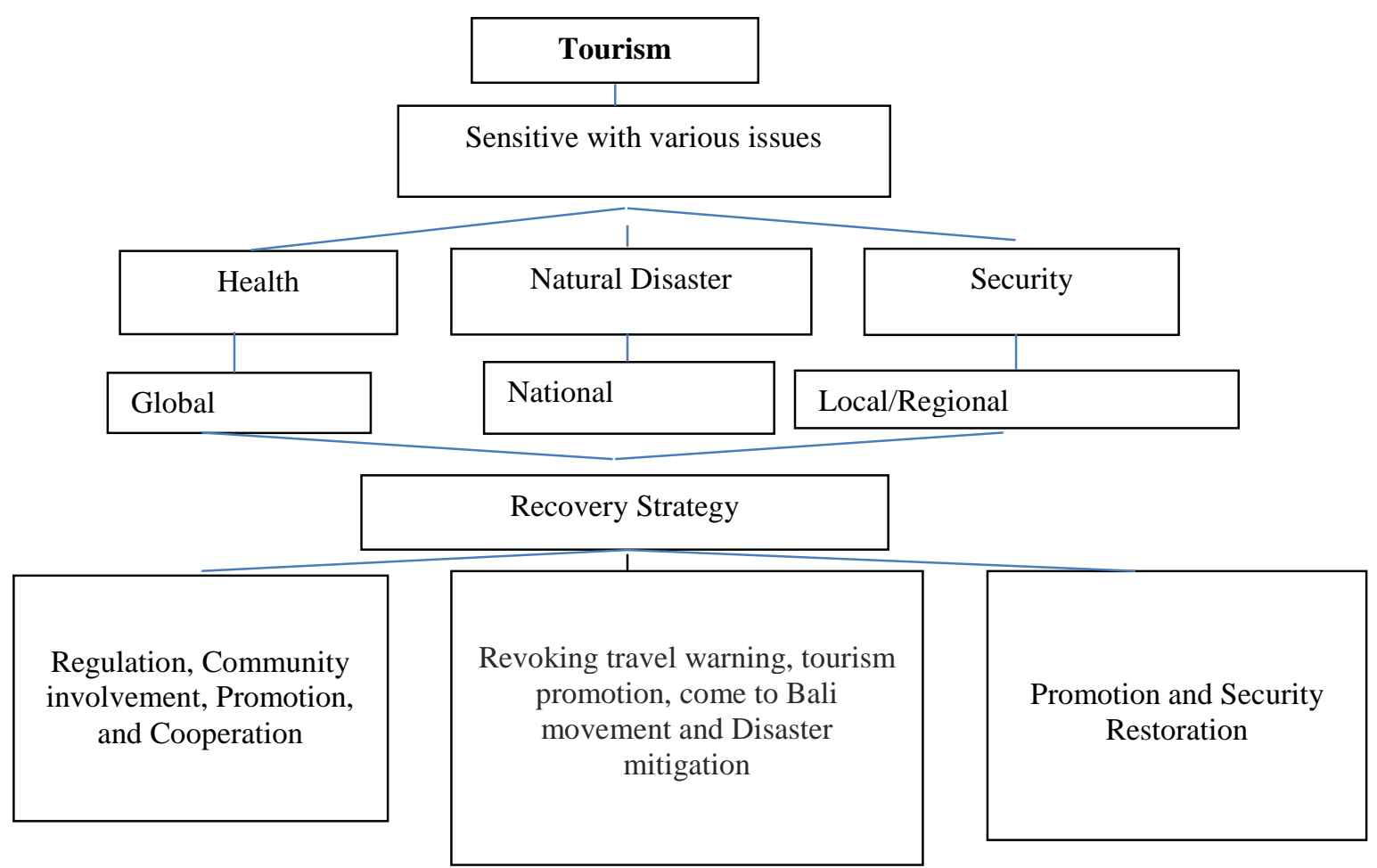

Figure 1. Framework of Acceleration Strategy of Tourism Sector amid COVID-19 Pandemic

Second, what strategy or effort must be done in accelerating or recovering so that tourism of Bali can run normally as before. Problem solving by using descriptive method, according to opinion by [11], suggesting that in qualitative research using analysis descriptive method will yield to an explanation concerning problem reality naturally in the descriptive form and not in the form of statistical numbers. Constructing based on findings in the form of the effect of COVID-19 pandemic against tourism and acceleration strategy of tourism sector in the 
province of Bali amid pandemic, can be the basis of this COVID-19 event. The data then later becomes the basis to draw up a strategy to accelerate Bali's tourism amid COVID-19 condition. The findings can be the basis for recommendation for regional government of Bali and is new theory finding. This comprehension is in line with their opinion [12], it is said that theoretical finding can be constructed on the empirical basis in the field.

\section{RESULTS AND DISCUSSION}

Entering the year of 2020, although COVID-19 had spread in China, but overall international and domestic tourists visiting Bali were still going normally. However, along with the increasingly COVID-19 spread in Indonesia, international flight to Bali was also being closed. Besides that, restriction of people movement inter-regional also being upheld, to prevent the pandemic spread from hotspot region to another region. The halting of Bali tourism industry had significant impact on economic condition and people's purchasing power. It was reflected from PDRB which suffering very deep contraction, monthly price stress which recorded as deflation, as well as money trading which recorded as net inflow. Based on the data, it is clearly seen that tourism is still a backbone for economy of Bali. Despite regional government of province of Bali continues to pursue diversification of economic growth sources, tourism is still needed to drive public economy.

\subsection{Impact of COVID-19 towards tourism sector in the province of Bali}

As predicted earlier, Bali's economy on quarter II2020 again suffering deeper contraction compared to previous quarter. According to calculation by Central Statistical Agency of Bali Province, the impact of COVID-19 towards Bali's economy on quarter II-2020 is very great, that is minus 10.98 percent (yoy), much lower compared to previous quarter which grew minus 1.14 percent (yoy). According to Trisno Nugroho, the Head of BI representative of Bali province (https://bali. tribunnews.com) "Economic contraction in Bali is the deepest, if compared to all provinces in Indonesia and much lower compared to national growth, that is minus 5.32 percent (yoy)". From the side of business, most of major businesses have negative growth, only 3 businesses have positive growth, namely information/ communication, health service, and real estate. Meanwhile, transportation sector and food \& beverages accommodation provider are suffering contraction at minus 39.48 percent and minus 33.10 percent, respectively. Both sectors is closely related to tourism, in which as a backbone of Bali's economy.

The halting of tourism sector is not only affecting to tourism management directly, but also to tourism supporting industrial sectors such as transportation service, hotel, and so forth. Description of tourism of Bali amid pandemic can be seen in Figure 2 to Figure 5 below respectively. Both sectors is closely related to tourism, in which as a backbone of Bali's economy. Impact on tourism depicts no tourist visit to tourist destinations, as described in Picture 2.2 above. Similar thing happens to tourism supporting sectors.

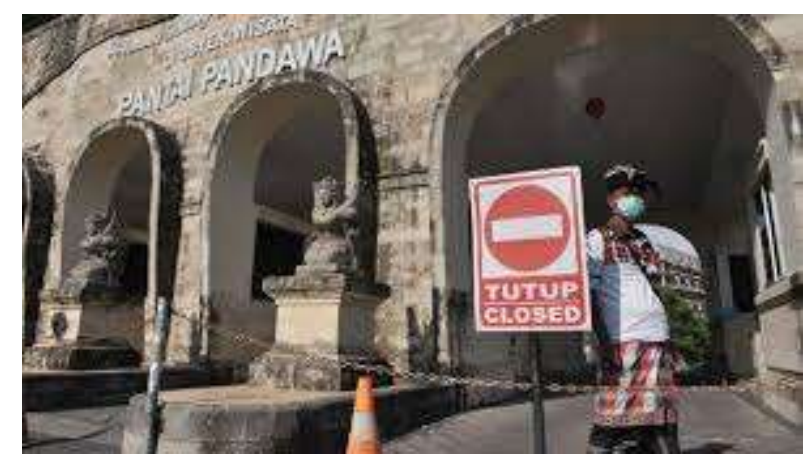

Figure 2. Closing of tourist area.

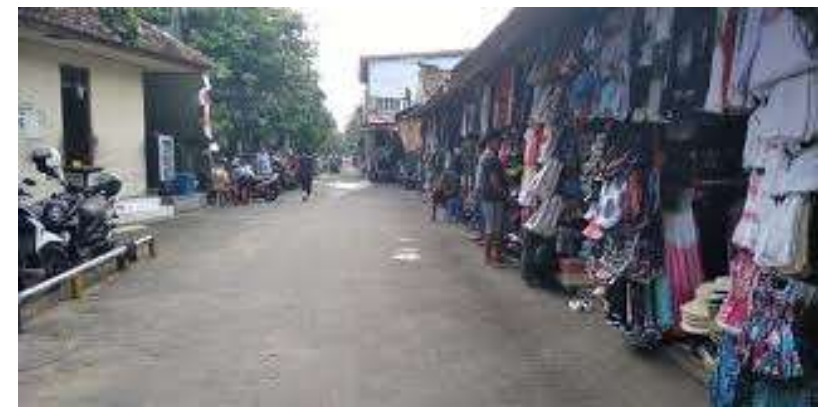

Figure 3. Art Centre desolate of visitors

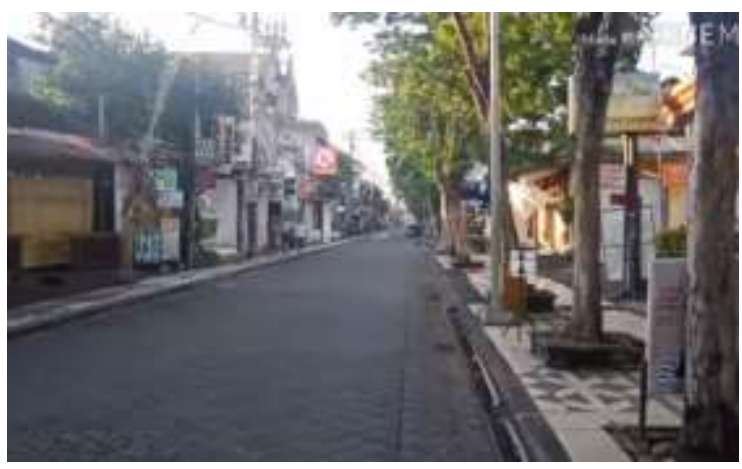

Figure 4. Street atmosphere in Kuta

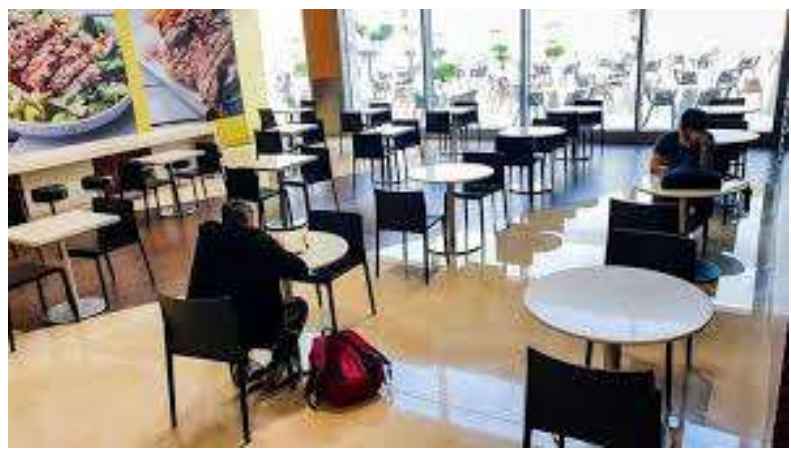


Figure 5. Restaurant atmosphere which desolate of visitors

After effect of no tourism activities has an impact on employees in tourism sector. IB Oka Dirga, Head of Industry and Employment Agency of Badung regency (http://bisnis.com) said that per March $31^{\text {st }}$, it is recorded that 1,781 employees in tourism industry were furloughed and 39 employees were terminated of employment (fired) in Badung. Further the impact was spread to the revenue of Hotel and Restaurant (PHR) taxes. The tax revenue is a regional tax that picked up by the Regency/City. According to I Wayan Suartana (https://www.balipost.com ), Bali with eight regencies and one city depends on PHR as the source of locally generated revenue in average of 60-70 percent. In 2020 the comparison between PAD and APBD Volume was 84 percent. APBD of Badung regency pegs PAD number at 5.3 trillion rupiah. With policy of abolishing PHR for one semester, it is expected that PAD will reduce 1.6 trillion rupiah up to 2 trillion rupiah, a very significant number. The prediction originated from the achievement of one semester $(0.5$ percent multiplied by 5.3 trillion rupiah multiplied by 60 percent). From the analysis of researcher, the scheme can be made as follows:

\subsection{Acceleration Strategy of Tourism Sector in Bali Province amid COVID-19 Pandemic}

Based on the impact created by COVID-19 pandemic, it is consisted of economic impact, PHR revenue, employment, and Brand Image, triggered by the decrease of tourist visit or tourism has suffered a very deep contraction, so it requires a strategy to restore the rate of tourist visit to Bali. Based on interview conducted by the researchers, by making three components namely tourism operators, government and tourism observers as informants, then the answer of respondents or informants is acquired as follows: Based on interview result conducted to tourism component, what strategy can be executed in accelerating tourism sector, here are several answers which was put forward as follows: Mr. I Ketut Sudin, tourism worker,

"Tourism of Bali must be back to normal, since majority of Balinese people work in tourism sector, tourist destinations to be soon opened again, likewise international flight must be opened soon".

What strategy that should be done? According to his opinion, there must be a government regulation both from central government and regional government regarding their stance to Bali’s tourism.

Similar opinion also put forward by Mr. I Wayan Puspa Negara, SP. What about strategy that should be done to accelerate tourism sector of Bali, he said that,

"Strategy that should be done is through 3 stages, first is by regulation, community involvement, cooperation and promotion. By regulation is to revoke the regulation by the Ministry of Law and Human Rights number 11 year 2020 regarding the banning of foreigners to enter the country of Republic of Indonesia. What it means with community involvement is how community nowadays to change their behavior in new norm life to comprehend and able to apply as well as to socialize health protocol shorted as CHSE: Cleanliness, Healthy, Safety and Environmental Preservation. If those issues can be prepared well then third step can be executed, that is technically holding cooperation between countries for which is called first stage travel bubble with countries in Southeast Asia (Malaysia, Singapore, Philippine, Thailand, Brunei Darussalam). Second stage is Asia Pacific countries. Third stage with European and Middle East countries, and fourth stage with Australia. Next is to carry out tourism promotion of Bali, which states that Bali is clean, healthy, secure, comfortable and sustainable, and supported with adequate Internet network facilities so that Nomad Digital tourists can do their activities without constraint.

Furthermore, it is opinion from Mr. Cokor-da Raka Darmawan, Head of Tourism Agency of Badung regency. What strategic effort to accelerate tourism in Bali or recovery of tourism of Bali.

"It is started with revoking regulation regarding banning of foreigners coming to Indonesia, and next to educate people especially they who are in frontier behavior which is known as Health Protocol, and if those two things have been applied well, then the third step is taken by conducting cooperation of tourist travel between countries which is known as Travel Bubble, which indirectly will create Digital Nomad.

Based on above opinions then it can be said that, acceleration strategy of tourism sector amid COVID-19 pandemic is through strategies as follows: First, revoking of regulation by the Ministry of Law and Human Rights Number 11 year 2020 regarding the banning of foreigners to enter the country of Republic of Indonesia. Second, involving the community by way of educating public especially tourism operators and creative economy regarding new life and put forward health protocol based on CHSE (Cleanliness, Health, Safety, and Environmental). Third, holding cooperation between countries in the form of Travel Bubble which is the limited opening of one country for several other countries with each having low or controlled corona virus (COVID-19) cases, through cooperation between countries, starting with cooperation with neighboring countries, later Asia Pacific, Europe and Middle East. And finally, the fourth, Promotion, which stating Bali as clean, healthy, secure, comfortable and sustainable region, and supported with adequate Internet Network 
facilities so that Nomad Digital tourists can do their activities without constraint.

This research finding is in line with research finding by Dian Herdiana (2020), which stated that COVID-19 pandemic affected economically, to employment and Brand image, however, the researcher also revealed more on a macro basis that is Bali's economy which suffered contraction. Further related to acceleration strategy of tourism sector, research finding is in line with research finding suggested by Oka Mahagangga and Victoria lelu Sabon. In outline is similar, namely community involvement, meaning that how community as tourism operators, to behave in line with health protocol.

Looking at the phenomena, then the researchers take conclusion that strategy being done will follow the tourism issue and create a new theory. It is in line with the opinion by Shepherd \& Roy, 2007, who stated that theoretical finding can be constructed on the empirical basis in the field.

\section{CONCLUSION}

Based on the result of discussion it can be concluded that the effect brought about by COVID-19 among others is the halting of tourism. As the results, the economy, regional revenue, employment, and brand image of tourism disturbed. It can also be concluded that acceleration strategy of tourism sector of Bali amid COVID-19 is through Regulation, community involvement, and cooperation and Tourism promotion.

We suggest that government of province of Bali immediately to carry out coordination with central government in particular the Ministry of Law and Human Rights related to the Regulation by Ministry No.11 year 2020 regarding the banning of foreigners to enter the country. For the follow-up, it can be in the form of community service in particular educating public to live a healthy life in accordance with qualified health protocol based on CHSE.

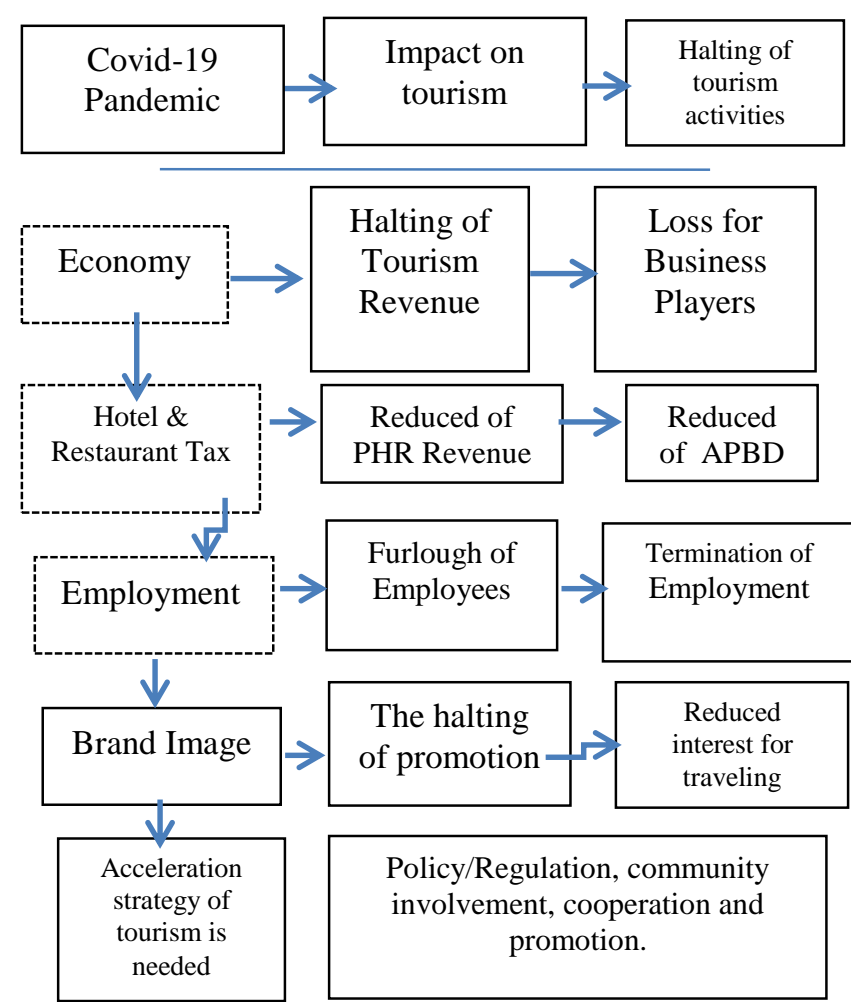

Figure 6. Scheme of Research Results

\section{REFERENCES}

[1] Abdurrahman Firdaus Thaha, "Dampak Covid-19 Terhadap UMKM di Indonesia,” J. Brand, 2020.

[2] D. Herdiana, "Rekomendasi Kebijakan Pemulihan Pariwisata Pasca Wabah Corona Virus Disease 2019 (Covid-19) di Kota Bandung," J. Master Pariwisata, 2020.

[3] I. G. A. O. Mahagangga, "The Role and Constraint of Tourism Recovery in Bali post Bali's bombing.," J. Tour. Anal., vol. Volume 12, 2012.

[4] Porter, "The Five Competitive Forc," 2008.

[5] WHO, "No Title," https://www.who.int/indonesia/ news. .

[6] Tommy, "The Meaning of regulation is: The Meaning, Objectives and Types," https:// kotakpintar.com/, 2020.

[7] V. lelu Sabon and Et.al, "Strategy of performance improvement in tourism sector of Indonesia in Asian Economic Community," Esensi, J. Bus. Manag., 2018.

[8] D. P. M. Rani, "Development of Tourism Potential in the Regency of Sumenep, Madura, East Java," Young Polit. J., vol. Vol. 3, pp. 412-421, 2014. 
[9] R. Resnawaty, "Strategy of Community Practice in the Development of Tourism based on Community," Share Soc. Work J., vol. Vol. 6, pp. 105-118, 2016.

[10] "Nabilla Ramadhian," https://travel. kompas.com. .

[11] U. Silalahi, Social Research Method. Bandung: PT. Refika Aditama, 2009.

[12] D. A. Shepherd and S. Roy, "Theory Building: A Review and Interaction,” J. Manag. 43, 2007. 